KS. WALDEMAR W. ŻUREK SDB - LUBLIN

\title{
NATIONAL FORUM OF THE DIRECTORS OF THE DIOCESAN ARCHIVES IN POLAND
}

The ending 2014 year has been full of anniversaries related to the church archive studies in Poland. We have celebrated the 10th anniversary of the functioning of the three diocesan archives: Zielona Góra, Koszalin and Szczecin. This year, it has been 50 years since the death (April 28, 1964) of Rev. Józef Nowacki, a distinguished and long-term director (1933-1964) of the Archdiocesan Archive in Poznań. And next year in November, an international symposium will be held in the Archdiocesan Archive in Poznan. This conference will begin the celebration of the 90th anniversary of the foundation of the above mentioned Archive ${ }^{1}$. In addition, this year the Metropolitan Archbishop of Poznań Stanisław Gądecki became the President of the Polish Episcopal Conference.

Under the patronage of the President of the Polish Episcopal Conference, the Metropolitan Archbishop of Poznań, Stanisław Gądecki and with his participation, the Archdiocesan Archive in Poznań, which has been managed by Rev. Roman Dworacki since 2002, organized the First National Forum of the Directors of the Diocesan Archives in Poland on 20-21 October 2014.

The Congress began with the Holy Mass concelebrated on 20 October in the small chapel of the Archdiocesan Seminary in Poznan (Wieżowa 2/4 Street). The principal celebrant was Rev. Józef Pater, Protonotary Apostolic from Wrocław. Forum sessions were held in the conference room of the Archdiocesan Archive building in Poznań. Since 2007 this archive has been housed in a renovated build-

${ }^{1}$ The Archdiocesan Archive in Poznan was founded in 1925 thanks to the efforts of the Suffragan Bishop of Poznań Stanisław Łukomski (1874-1948) and the diocesan archivist Rev. Edmund Majkowski. The Archbishop of Gniezno and Poznań Cardinal Edmund Dalbor, Polish Primate signed the foundation document. It was the first church institution of its kind within the reborn Polish State, which is currently managed by the sixth consecutive director Rev. Roman Dworacki. The 1970s were extremely important for this Archive in terms of sharing archive materials; the entire collection of archive materials of the Old Polish period was microfilmed, along with a collection of registry records. At that time the director of the Archive was Rev. Marian Banaszak (1971-1990). 
ing in Ostrów Tumski in Poznań at Rev. Ignacy Posadzy 2 Street $^{2}$. The host and organizer of the Forum, director Dworacki began the morning session with the greetings of those who arrived (mainly the directors of the diocesan archives) in Poland; he presented individual directors of the diocesan archives (,We know each other only by sight"), who in turn spoke about the date of the erection of the archive, its activities, employed workers and important documents and collections stored in the archive. The following directors were presented: Dr Halina Dudała (the Archdiocesan Archive in Katowice), Rev. Dr Tadeusz Kasabuła (the Archdiocesan Archive in Białystok), Sister Karolina Anna Kołodziejczyk (an employee of the Archdiocesan Archive in Lublin), Rev. Dr Andrzej Kwaśniewski (the Diocesan Archive in Kielce), Rev. Dariusz Piotr Majewski (the Diocesan Archive in Płock $^{3}$ ), Rev. Prof. Dr Hab. Józef Pater (the Archdiocesan Archive and Museum, and the Chapter Library in Wrocław), Rev. Robert Masalski (the Archdiocesan Archive in Szczecin), Rev. Dr Tadeusz Ceynowa (the Archive of the Diocese of Koszalin and Kołobrzeg), Rev. Prof. Dr Hab. Atanazy Nadolny (the Diocesan Archive in Pelplin), Rev. Dr Michał Sołomieniuk (the Archdiocesan Archive in Gniezno $^{4}$ ), Rev. Dr Hab. Jacek Urban (the Archive of the Metropolitan Curia in Cracow $^{5}$ ), Rev. Tomasz Zmarzły, MA (the Diocesan Archive and Museum in Sosnowiec, in a start-up stage), Rev. Dr Hab. Waldemar Żurek (the director of the Institute of Church Archives, Libraries and Museums of the Catholic University of Lublin), Rev. Dr Hab. Władysław Wlaźlak from Rzeszów (the President of the Association of the Church Archivists ${ }^{6}$ ). Finally, director, Rev. Dworacki introduced himself, his deputy Rev. Dr Jan Maria Musielak and the Archdiocesan Archive in Poznań.

The session was divided into three parts. The first two in the morning and the third in the afternoon. The first part was chaired by Rev. Jan Maria Musielak, deputy director of the Archdiocesan Archive in Poznań. The first speaker was Rev. Dr Tadeusz Ceynowa - the director from Koszalin who presented the topic: „The

${ }^{2}$ Since 2007, the Archdiocesan Archive has been housed in a renovated building in Ostrów Tumski at Rev. Ignacy Posadzy 2 Street. Through implementing the Integrated Operational Programme for Regional Development the present building was adapted to the needs of the Archive and equipped with modern equipment.

${ }^{3}$ References to the archive come from the early fifteenth century. From 1957, Rev. Tadeusz Żebrowski was its director (as well as a library director of the Seminary) - until 2001. He died on 8 October 2014.

${ }^{4}$ This archive functions as a curial department because it has no decree of erection as an archive, and it has no legal personality either.

${ }^{5}$ Actually, there are two church archives in Cracow: the Chapter Archive in Wawel and the Archive of the Metropolitan Curia in Franciscan Street.

${ }^{6}$ The Association of the Church Archivists in Poland - was approved at the 325th Plenary Meeting of the Conference of the Polish Episcopate (Częstochowa, 27-28 November 2003.). The decree of erection was issued on 1 December 2003 by the President of the Episcopal Conference, Polish Primate, Cardinal Józef Glemp. The Association, based in Katowice, received legal personality on 1 February 2005. In accordance with Article 19 of the Concordat the Association conforms to the norms of canon law in terms of the creation, management, activities and relations within the Church, which is recognized by the State. 
issue of collecting archival collections". Another talk was given by Dr Halina Dudała from Katowice; she discussed: „The Book of registry records and genealogical research".

The second part of the morning session was chaired by Rev. Dr Hab. Mieczysław Różański. Rev. Dr Robert Masalski from Szczecin spoke on „Preservation of archival materials and possibilities of raising funds”. Rev. Dr Andrzej Kwaśniewski from Kielce discussed „Scientific and cultural initiatives, and Blessed Wincenty Kadłubek Society of Friends of the Diocesan Archive in Kielce".

The third part of the session was chaired by Rev. Dr Hab. Waldemar Żurek from Lublin. First, Rev. Dr Jan Maria Musielak spoke on: „The CAAP i e Duplicate or digitization in archival practice". The next and last paper was presented by the host of the forum Rev. Roman Dworacki, S.T.L.: „KOHA and ATOM - Electronic archival inventories".

After the talks of each of the three parts of the program there was a discussion on the topics presented to listeners and participants. The third and last part of the Forum included the 10th General Assembly of the Association of the Church Archivists in Poland. The President of the Association, Rev. Władysław Wlaźlak from Rzeszów read the report on the activities of the Association and the financial report. After the discussion about the reports, the Board of the Association received approval in the second ballot. The President emphasized the fact that they systematically published a bulletin of the Association, organized conferences and they had recently established closer cooperation between the Association of the Church Archivists and the Institute of National Remembrance in Rzeszów in the field of digitization of church archival materials. By the decision of the Board of the Association, five people were made the members of the Association of the Church Archivists.

The last point of the first day of the Forum was visiting the National Archive in Poznań and Passenger Automobile Factory, Volkswagen Poznań. In a discussion with the director of the state archive the issue of the cooperation between the state archives and the church ones was raised. In addition, it was emphasized that the State is responsible for the national archival collection, which is also owned by the Church. Visiting the Passenger Automobile Factory, including its production lines had an established goal: to gain the information about the organizational work of the factory, which is one of the best in Europe, if not the world.

The morning of the second day of the Forum began with the Holy Mass concelebrated in the chapel of the Archdiocesan Seminary. The principal celebrant was the Archbishop Stanisław Gądecki, the President of the Polish Episcopal Conference. After breakfast there was a meeting of participants with the Metropolitan Archbishop of Poznań. During that meeting, the participants discussed the issues and topics related to the functioning of the church archives. The tone and nature of the discussion were set by the director from Poznań, Rev. Dworacki. In addition, they talked about legal issues relating to the activities of the church archives; among others, they pondered if it would be more appropriate and beneficial for the diocesan archives to possess legal personality. The votes of the participants on this issue were divided. Most of the them were for giving each archive such personality. 
The last point of the meeting: „Here the Polish statehood began , was a visit to the modern museum - Interactive Centre of the History of Ostrów Tumski, where the visitors could see a special multimedia program and learn about the history and significance of Ostrów Tumski in Poznan, its role and place in the history of our country. They could also gain knowledge about the first Polish bishop Jordan, his episcopal see and the Diocese of Poznan. This presentation is the highlight of the Royal-Imperial Route, the aim of which is to increase the awareness and respect for the cultural heritage of the city.

The two-day session was an opportunity to discuss issues related to the collection of archive materials, their conservation, description, sharing and digitization, which gave participants additional information on the collections of individual archives. Nowadays essential problem is under-financing of the church archives and lack of the fixed budget for research, preservation and service. The issue which is still open is the participation of the State in supporting the activities of these church institutions and cataloging church heritage of the Polish culture. The time for discussion after each presentation enabled all participants to speak on a given subject and exchange their views. 